\title{
Comparative analysis of four methods to extract DNA from paraffin-embedded tissues: effect on downstream molecular applications
}

\author{
Cornelis JJ Huijsmans ${ }^{1 *}$, Jan Damen², Johannes C van der Linden², Paul HM Savelkoul ${ }^{3}$, Mirjam HA Hermans ${ }^{1}$
}

\begin{abstract}
Background: A large portion of tissues stored worldwide for diagnostic purposes is formalin-fixed and paraffinembedded (FFPE). These FFPE-archived tissues are an extremely valuable source for retrospective (genetic) studies. These include mutation screening in cancer-critical genes as well as pathogen detection. In this study we evaluated the impact of several widely used DNA extraction methods on the quality of molecular diagnostics on FFPE tissues.

Findings: We compared 4 DNA extraction methods from 4 identically processed FFPE mammary-, prostate-, colonand lung tissues with regard to PCR inhibition, real time SNP detection and amplifiable fragment size. The extraction methods, with and without proteinase K pre-treatment, tested were: 1) heat-treatment, 2) QIAamp DNAblood-mini-kit, 3) EasyMAG NucliSens and 4) Gentra Capture-Column-kit.

Amplifiable DNA fragment size was assessed by multiplexed 200-400-600 bp PCR and appeared highly influenced by the extraction method used. Proteinase $\mathrm{K}$ pre-treatment was a prerequisite for proper purification of DNA from FFPE. Extractions with QIAamp, EasyMAG and heat-treatment were found suitable for amplification of fragments up to $400 \mathrm{bp}$ from all tissues, $600 \mathrm{bp}$ amplification was marginally successful (best was QIAamp). QIAamp and EasyMAG extracts were found suitable for downstream real time SNP detection. Gentra extraction was unsuitable. Hands-on time was lowest for heat-treatment, followed by EasyMAG.
\end{abstract}

Conclusions: We conclude that the extraction method plays an important role with regard to performance in downstream molecular applications.

\section{Findings}

Due to the tremendous progress in molecular pathology during the last decade, molecular techniques are moving rapidly from research to routine use in diagnostic pathology. At present, routine tests include for example the detection of bacteria and viruses [1-7], neoplasmassociated mutations [8-10], microsatellite instability $[11,12]$ and up- and down-regulation of mRNA's [13]. Archives of formalin-fixed paraffin-embedded (FFPE) tissues -that are often maintained over decades- represent an extraordinary source of morphologically well defined tissues that now allow retrospective studies to

\footnotetext{
* Correspondence: r.huysmans@jbz.nl

'Laboratory of Molecular Diagnostics, Jeroen Bosch Hospital,

's-Hertogenbosch, The Netherlands

Full list of author information is available at the end of the article
}

correlate molecular findings with therapy and clinical outcome [14].

However, the application of molecular DNA-based techniques to FFPE tissues suffers from challenges. Formalin fixation, the most widely used fixative in histopathology, has many advantages such as the ease of tissue handling, the possibility of long-term storage, an optimal histological quality and its availability in large quantities at low price $[15,16]$. Unfortunately formalin fixation induces DNA-tissue protein cross-links, which can prevent amplification. In addition, nucleic acid fragmentation may occur in formalin fixed tissue due to aging of the specimen or the $\mathrm{pH}$ of the fixative [17]. Previous studies have shown that DNA extraction and subsequent downstream processes such as PCR from FFPE tissues is difficult, especially when longer stretches of DNA templates are targeted [18]. It has been

\section{Ciomed Central}


reported that DNA fragments of up to only 100-300 bp are obtained from FFPE tissues [19].

To recover nucleic acids from non-fixed tissues we routinely combine proteinase $\mathrm{K}$ (prot. $\mathrm{K}$ ) digestion with commercial extraction methods. The aim of this study was to test whether DNA isolation techniques routinely available in molecular diagnostic laboratories can be applied to FFPE tissues. In addition, we think it is handy to employ DNA extraction kits that are suitable for the extraction of DNA from a wide variety of patient materials, e.g. blood, buccal swabs and FFPE tissues. We therefore compared four different extraction protocols with and without prot. $\mathrm{K}$ digestion, and evaluated the impact of these DNA isolation methods on downstream molecular techniques. The extractions tested were: 1 ) heat-treatment, 2) QIAamp DNA-blood-mini-kit extraction, 3) EasyMAG NucliSens extraction and 4) Gentra Capture-Column-kit extraction.

Experiments were carried out regarding i) the inhibition of PCR by monitoring amplification of an internal control DNA virus, ii) the performance of the isolated DNA in SNP analysis by real time PCR and iii) performance in a conventional multiplex PCR amplifying 200, 400 and 600 bp human DNA fragments. Studies comparing the suitability of different DNA extraction methods such as (modified) phenol-chloroform extraction, boiling, microwave and QIAamp DNA-blood-mini-kit extraction have been published [20-24]. However these studies did not include a comparison of the in this study described commercial methods, which are routinely used by hospital laboratories when performing molecular diagnostics.

The data presented here indicate that proteinase $\mathrm{K}$ digestion is required for obtaining DNA of sufficient quality by all 4 extraction methods. The size of the amplifiable DNA fragments highly depended on the extraction method. QIAamp extraction and heat-treatment in combination with proteinase $K$ digestion resulted in amplification of the longest DNA fragments - up to 600 bp. Amplification inhibitors were found in all Gentra extracts and in one colon tissue extract after prot. $\mathrm{K}$ digestion and heat-treatment. EasyMAG NucliSens extraction and the QIAamp method seemed to be equally effective in extracting $200 \mathrm{bp}$ fragments, and therefore suitable for real time SNP detection. An advantage of heat-treatment and the EasyMAG NucliSens extraction was their lower hands-on time.

\section{Methods}

\section{Experimental set-up}

The workflow of the presented study is described in figure 1. Four tissues (A-D) were subjected to proteinase $\mathrm{K}$ digestion and no proteinase $\mathrm{K}$ digestion. Subsequently, 4 different extraction methods were performed:
1) heat-treatment, 2) QIAamp DNA-blood-mini-kit extraction, 3) EasyMAG NucliSens extraction and 4) Gentra Capture-Column-kit extraction. All extracts were tested regarding: i) cumulative effect of PCR inhibition and extraction efficiency, ii) performance in real time SNP detection and iii) Performance in conventional multiplex PCR amplifying 200, 400 and 600 bp human genomic DNA fragments.

\section{Tissue processing}

Four randomly chosen biopsies, taken for diverse clinical purposes, from different patients and organs were used for this study: A. mammary, B. colon, C. prostate and D. lung. The tissues were rendered anonymous before use in this study and were formalin-fixed and paraffinembedded 1-4 weeks ago. Tissues were fixed in 0.01 $\mathrm{mol} / \mathrm{L}$ buffered $(0.005 \mathrm{~mol} / \mathrm{L}$ disodium hydrogen phosphate anhydrous and $0.005 \mathrm{~mol} / \mathrm{L}$ sodium dihydrogen phosphate dihydrate, $\mathrm{pH}$ 7.0) 10\% formalin, and processed for paraffin embedding using a Tissue-Tek VIP 5 (Sakura, Torrance, USA). The dehydration program consisted of 14 steps of 1 hour under continuous agitation, pressure, vacuum, and heating. At $40^{\circ} \mathrm{C}$, two $10 \%$ formalin steps were followed by one $70 \%(\mathrm{v} / \mathrm{v})$ ethanol step, two $96 \%$ ethanol steps, three $100 \%$ ethanol steps, and two $100 \%$ xylene steps. Paraffin embedding was done at $60^{\circ} \mathrm{C}$ in four $100 \%$ paraffin steps.

\section{DNA extractions}

The four DNA isolation procedures were: heat-treatment, QIAamp DNA-blood-mini-kit extraction (silica membrane-based column extraction; Qiagen, Hilden, Germany), EasyMAG NucliSens extraction (magnetic silica beads-based extraction; Biomerieux, Boxtel, The Netherlands) and Gentra Capture-Column-kit extraction (silica membrane-based column extraction; Gentra Systems Inc, Minneapolis, USA).

Paraffin-embedded tissues were trimmed of paraffin excess and cut into 3- $\mu \mathrm{M}$-thick sections. Approximately 1 to $1.5 \mathrm{~cm}^{2}$ of sectioned tissue (a single section or short ribbons depending on the surface per section) was put in $250 \mu \mathrm{L}$ of digestion solution (digestion solution with proteinase $\mathrm{K}$ was prepared by adding $100 \mu \mathrm{L}$ of proteinase $\mathrm{K}$ solution $(20 \mathrm{mg} / \mathrm{mL}$; Roche Diagnostics $\mathrm{GmbH}$, Mannheim, Germany) and $10 \mu \mathrm{L}$ of Tween 20 (Merck BV, Amsterdam, The Netherlands) to $2 \mathrm{~mL}$ of TE buffer $(1 \mathrm{mmol} / \mathrm{L}$ ethylenediaminetetraacetic acid, and $10 \mathrm{mmol} / \mathrm{L}$ Tris-HCl buffer, $\mathrm{pH} 8.0)$ ) and incubated overnight at $45^{\circ} \mathrm{C}$. Proteinase $\mathrm{K}$ was inactivated the next day by incubation at $100^{\circ} \mathrm{C}$ for $15-30$ minutes. Afterwards, samples were centrifuged for 2 minutes at 14,000 rpm.

From each material eight paraffin sections were cut, 4 were digested in digestion solution with proteinase $\mathrm{K}$ 


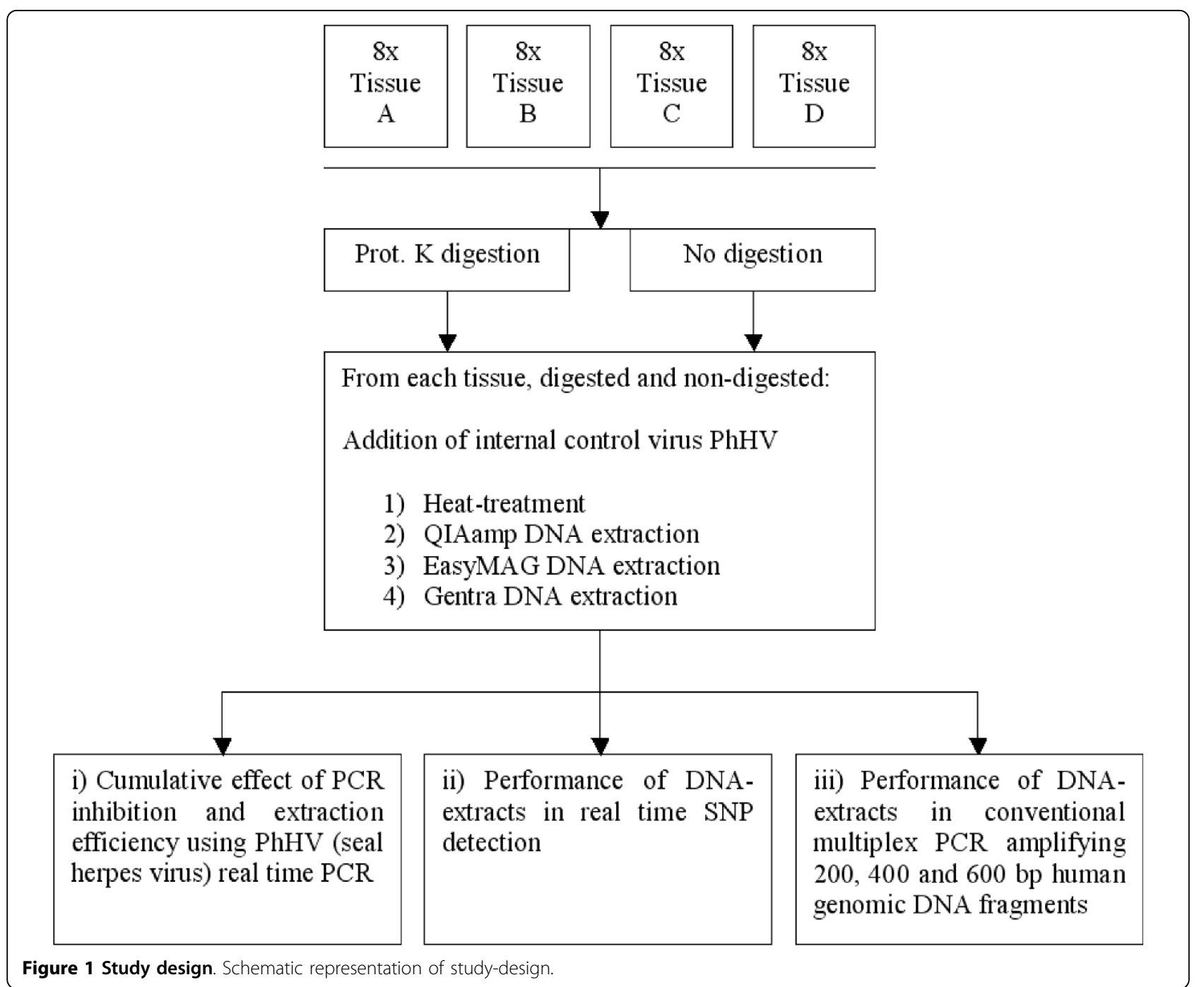

(according to the method described above) and 4 were submerged in digestion solution without proteinase $K$. All 32 samples were further processed as described above. To assure an equal quantity of DNA in each procedure, the supernatants -located beneath the paraffin cap- from the 4 proteinase $\mathrm{K}$ digested samples as well as the 4 non-digested samples were pooled for each material. These pools were homogenized and processed as detailed below.

\section{Heat treatment}

Two-hundred $\mu \mathrm{L}$ of pool was mixed with $10 \mu \mathrm{L}$ of Phocine herpes virus (PhHV, seal herpes virus, kindly provided by the Erasmus Medical Centre in Rotterdam, The Netherlands), which served as an internal extraction control, and was used directly in the downstream applications.

\section{QIAamp DNA-blood-mini-kit extraction}

Two-hundred $\mu \mathrm{L}$ pool and $10 \mu \mathrm{L}$ of PhHV were added to $200 \mu \mathrm{L}$ AL buffer, homogenized and incubated for
$10 \mathrm{~min}$. at room temperature. Two-hundred $\mu \mathrm{L}$ of $96 \%$ ethanol (Merck KgaG, Darmstadt, Germany) was added. The mixture was transferred to a QIAamp column and centrifuged for $1 \mathrm{~min}$. at 8,000 rcf. The column was put in a new collection tube, $500 \mu \mathrm{L}$ AW1 buffer was added and centrifuged for $1 \mathrm{~min}$. at 8,000 rcf. This procedure was repeated with $500 \mu \mathrm{L}$ AW2 buffer and the column was centrifuged for $1 \mathrm{~min}$. at 14,000 rcf. To remove all ethanol from the column it was put in a new collection tube and then subjected to a dry spin for $1 \mathrm{~min}$. at 14,000 rcf. Elution was performed by adding $200 \mu \mathrm{L}$ EL buffer, incubating for $5 \mathrm{~min}$. at room temperature followed by centrifugation for $1 \mathrm{~min}$. at 8,000 rcf.

\section{EasyMAG NucliSens extraction}

Two-hundred $\mu \mathrm{L}$ pool and $10 \mu \mathrm{L}$ of PhHV were added to $2 \mathrm{~mL}$ NucliSens lysis buffer, homogenized and incubated for $10 \mathrm{~min}$. at room temperature. The mixture was then added to the EasyMAG vessel and $100 \mu \mathrm{L}$ of diluted magnetic silica $(50 \mu \mathrm{L}$ silica $+50 \mu \mathrm{L}$ ultrapure 
water) was subsequently added. The DNA was extracted on the EasyMAG machine using the "Generic 2.0.1" program. Elution was performed in $200 \mu \mathrm{L}$ NucliSens Extraction buffer 3.

\section{Gentra Capture-Column-kit extraction}

Two-hundred $\mu \mathrm{L}$ pool and $10 \mu \mathrm{L}$ of PhHV were directly added to the column and incubated for $5 \mathrm{~min}$. at room temperature. Four-hundred $\mu \mathrm{L}$ of Purification Solution 1 was added followed by $5 \mathrm{~min}$. incubation at room temperature and a $15 \mathrm{sec}$. centrifugation step at 8,000 rcf. This step was performed twice. Subsequently $200 \mu \mathrm{L}$ of Elution Solution 2 was added followed by a 15 sec. centrifugation step at 8,000 rcf. To elute the purified DNA, $200 \mu \mathrm{L}$ of Elution Solution 2 was added to the column and incubated for $10 \mathrm{~min}$. at $100^{\circ} \mathrm{C}$. Collection of the DNA was performed by centrifugation for $25 \mathrm{sec}$. at 8,000 rcf.

\section{Internal control amplification}

A PhHV specific real time PCR was performed. Twentyfive $\mu \mathrm{L}$ of PCR, using a homebrew "JBZ" $4 \times$ mastermix, contained $20 \mathrm{mmol} / \mathrm{L}$ Tris- $\mathrm{HCl}, \mathrm{pH} 8.4,50 \mathrm{mmol} / \mathrm{L}$ $\mathrm{KCl}, 3 \mathrm{mmol} / \mathrm{L} \mathrm{MgCl}_{2}$ (prepared from 10× PCR buffer and $50 \mathrm{mmol} / \mathrm{L} \mathrm{MgCl}_{2}$ solution delivered with Platinum Taq polymerase), $0.75 \mathrm{U}$ of Platinum Taq polymerase (Invitrogen BV, Breda, The Netherlands), 4\% glycerol (molecular biology grade; Calbiochem, VWR International BV, Amsterdam, The Netherlands), $200 \mu \mathrm{mol} / \mathrm{L}$ of each dNTP (Invitrogen BV), $0.5 \mu \mathrm{L}$ of Rox reference dye (Invitrogen BV), $300 \mathrm{nM}$ of PhHV forward primer 5'-GGG CGA ATC ACA GAT TGA ATC-3', 300 nM of PhHV reverse primer 5'-GCG GTT CCA AAC GTA CCA A-3', 100 nM PhHV TaqMan probe 5'-FAM-TTT TTA TGT GTC CGC CAC CAT CTG GAT CTAMRA-3' and $10 \mu \mathrm{L}$ extracted DNA [25]. Real time PCR was performed in an ABI Prism 7000 SDS (Applied Biosystems (ABI), Foster City CA, USA) for 2 minutes at $50^{\circ} \mathrm{C}, 10$ minutes at $95^{\circ} \mathrm{C}$, followed by 45 cycles of 15 seconds at $95^{\circ} \mathrm{C}$ and 1 minute at $60^{\circ} \mathrm{C}$.

\section{SNP analysis using real time PCR}

Predesigned TaqMan Assays-on-Demand SNP genotyping products rs2043731 and rs1350138 (ABI) were used according to the manufacturer's instructions. Two mastermixes were tested: the homebrew JBZ $4 \times$ mastermix and the commercial ABI $2 \times$ TaqMan Universal PCR mastermix. Twenty-five $\mu \mathrm{L}$ of PCR, using the JBZ $4 \times$ mastermix contained, $20 \mathrm{mmol} / \mathrm{L}$ Tris- $\mathrm{HCl}, \mathrm{pH} 8.4,50 \mathrm{mmol} / \mathrm{L} \mathrm{KCl}$, $3 \mathrm{mmol} / \mathrm{L}_{\mathrm{MgCl}_{2}}$ (prepared from 10× PCR buffer and 50 $\mathrm{mmol} / \mathrm{L} \mathrm{MgCl}_{2}$ solution delivered with Platinum Taq polymerase), $0.75 \mathrm{U}$ of Platinum Taq polymerase (Invitrogen BV, Breda, The Netherlands), $4 \%$ glycerol (molecular biology grade; Calbiochem, VWR International BV, Amsterdam, The Netherlands), $200 \mu \mathrm{mol} / \mathrm{L}$ of each dNTP
(Invitrogen BV), $0.5 \mu \mathrm{L}$ of Rox reference dye (Invitrogen $\mathrm{BV}), 1.25 \mu \mathrm{L}$ of predeveloped assay reagent from the Assays-on-Demand SNP genotyping products (ABI) containing two primers and two MGB TaqMan probes $\left(5^{\prime}\right.$ VIC for allele 1, 5' FAM for allele 2 and a 3 ' black hole quencher for both alleles), and $11.25 \mu \mathrm{L}$ of target DNA. Twenty-five $\mu \mathrm{L}$ of PCR, using the commercial mastermix, contained $12.5 \mu \mathrm{L}$ of $2 \times$ TaqMan Universal PCR Master$\operatorname{mix}(\mathrm{ABI}), 1.25 \mu \mathrm{L}$ of predeveloped assay reagent from the Assays-on-Demand SNP genotyping products and 11.25 $\mu \mathrm{L}$ of target DNA. Real time PCR was performed in an ABI Prism 7000 SDS (ABI) for 2 minutes at $50^{\circ} \mathrm{C}, 10 \mathrm{~min}$ utes at $95^{\circ} \mathrm{C}$, followed by 45 cycles of 15 seconds at $95^{\circ} \mathrm{C}$ and 1 minute at $60^{\circ} \mathrm{C}$.

\section{Assessment of maximum amplicon length}

Five $\mu \mathrm{L}$ of eluate was added to $12.5 \mu \mathrm{L}$ of $2 \times$ Qiagen Multiplex Mastermix ${ }^{\circledR}$ (Qiagen), $2.5 \mu \mathrm{L}$ of primer pool (containing $2 \mu \mathrm{M}$ of each primer) and $5 \mu \mathrm{L}$ of ultrapure water (Gibco BRL division of Invitrogen, Gaithersburg, USA). Amplification was performed in a Veriti (ABI): $5 \mathrm{~min}$. at $95^{\circ} \mathrm{C}, 35$ cycles of $30 \mathrm{sec}$. at $94^{\circ} \mathrm{C}, 1: 30 \mathrm{~min}$. at $57^{\circ} \mathrm{C}$ and $1: 30 \mathrm{~min}$. at $72^{\circ} \mathrm{C}$, followed by $10 \mathrm{~min}$. at $72^{\circ} \mathrm{C}$, and finally $\infty$ at $10^{\circ} \mathrm{C}$.

Separation on gel, visualization and quantification of the PCR products was performed in a 2100 BioAnalyzer (Agilent Technologies, Santa Clara CA, USA) using the DNA 1000 series II kit according to the manufacturer's protocol.

\section{Results}

\section{Internal control amplification}

To monitor the presence of inhibiting substances in the PCR, $10 \mu \mathrm{L}$ of seal herpes virus (PhHV) was added to each material before DNA isolation and a PhHV specific real time PCR was performed after DNA isolation. The fixed quantity of PhHV added to each extraction method in this study is exactly in accordance with the quantity used in our routine diagnostics. Based on 340 measurements of DNA isolations for diagnostic purposes, the expected $\mathrm{Ct}$ value is the mean $\mathrm{Ct}$ value = 25.8; coefficient of variation, $2.5 \%$ (data not shown); the threshold for inhibition was set at $\mathrm{Ct} 27.7$ being the mean +3 standard deviations. DNA isolates with PhHV values that exceed 27.7 are considered to be inhibited.

Figure 2 shows the mean PhHV PCR Ct values of the 4 tissues (A, B, C and D) for the different extraction methods. PhHV amplification after Gentra extraction from all four tissues (with and without prot. K pre-treatment; Ct $33.1 \pm 0.4$ and $C t 34.0 \pm 1.2$, respectively) and prot. K plus heat-treatment for colon tissue B ( Ct 30.0) generated $\mathrm{Ct}$ values $>27.7$ indicating PCR inhibition. PhHV amplification of DNA-extracts obtained using all other methods showed no inhibition ( $\mathrm{Ct}$ values $<27.7$ ). 


\section{Mean PhHV Ct values}

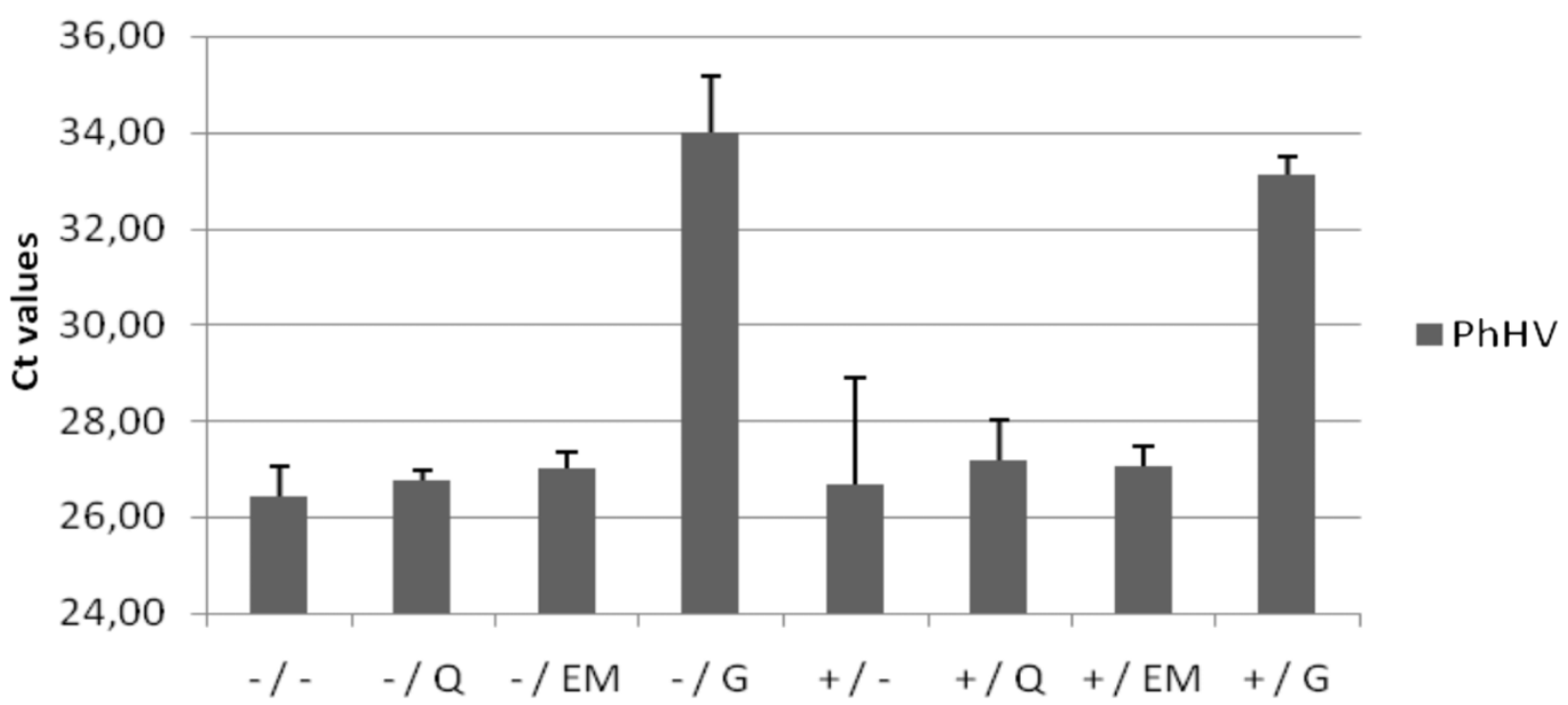

Figure 2 Internal control amplification. Mean Ct value of PhHV PCR of the 4 materials (A, B, C and D) for the different extraction methods. The $+/$ and $-/$ indicate the use of proteinase $\mathrm{K}$ digestion or no digestion, respectively. The different extraction methods are indicated by: heattreatment =/-, QIAamp DNA extraction =/Q, EasyMAG DNA extraction =/EM, Gentra DNA extraction =/G.

\section{SNP analysis using real time PCR}

To determine the suitability of the different DNA extracts for SNP analysis, real time amplification using Assays-On-Demand SNP genotyping products was performed. Different PCR buffer systems and/or different Taq polymerases may yield different real time PCR results [26,27]. We therefore evaluated 2 different mastermixes.

Figure 3A shows a representative example (colon tissue) of real time amplification component plots using SNP assay rs1350138 in JBZ $4 \times$ (home made) mastermix and $\mathrm{ABI} 2 \times$ mastermix. Figure $3 \mathrm{~B}$ shows the mean $\mathrm{Ct}$ values for the different DNA extraction procedures after real time amplification using SNP Assays-On-Demand Genotyping products rs2043731 and rs1350138 in JBZ $4 \times$ mastermix and ABI $2 \times$ mastermix. Use of the JBZ $4 \times$ mastermix resulted in slightly higher fluorescence and lower mean $\mathrm{Ct}$ values than the ABI $2 \times$ mastermix. Mean Ct's were lowest after prot. $\mathrm{K}$ digestion followed by QIAamp and EasyMAG extraction (mean $\mathrm{Ct}$ value in $\mathrm{JBZ}$ mix $=26.5$ and 26.6, respectively).

\section{Assessment of maximum amplicon length}

A multiplex PCR was performed to assess the ability of 200, 400 and 600 bp human DNA fragments to be amplified using the DNA yielded by the different extraction methods. Visualization of the PCR products on gel of representative tissue B (colon) is shown in figure 4 . The mean yields of the multiplexed $200 \mathrm{bp}, 400 \mathrm{bp}$ and
$600 \mathrm{bp}$ PCR products of 4 different tissues (A, B, C and $D)$ for the different extraction methods are shown in figure 5. To compare the methods' yields the QIAamp DNA extraction in combination with proteinase $\mathrm{K}$ digestion was set at $100 \%$. The multiplex amplification of DNA extracted by prot. $\mathrm{K}$ digestion in combination with QIAamp, EasyMAG or heat-treatment extracts was successful for fragments up to $400 \mathrm{bp}$ from all tissues (400 bp amplicon yields of $11.0 \pm 1.2 \mathrm{ng} / \mu \mathrm{L}, 8.2 \pm 5.8 \mathrm{ng} / \mu \mathrm{L}$ and $9.02 \pm 4.56 \mathrm{ng} / \mu \mathrm{L}$, respectively), $600 \mathrm{bp}$ amplification was marginally successful in $3 / 4$ tissues for QIAamp and EasyMAG and in $4 / 4$ tissues for heattreatment with low yields $(6.5 \pm 8.2 \mathrm{ng} / \mu \mathrm{L}, 3.5 \pm 4.6 \mathrm{ng} /$ $\mu \mathrm{L}$ and $3.42 \pm 4.96 \mathrm{ng} / \mu \mathrm{L}$, respectively).

\section{Discussion}

Currently routine molecular techniques are increasingly used on FFPE tissues. An important basic requirement is optimal DNA preparation. We tested human DNA extracts from 4 commonly used DNA extraction methods for the presence of inhibiting substances, and in two downstream applications: real time SNP amplification and multiplexed 200-400-600 bp PCR.

It has to be taken into account that this study was performed with relatively fresh specimens -common practice when the sample is investigated for diagnostic related purposes- and that the formalin fixative was buffered. Both age of tissue blocks and buffering capacity of formalin fixative are known to be important factors that 


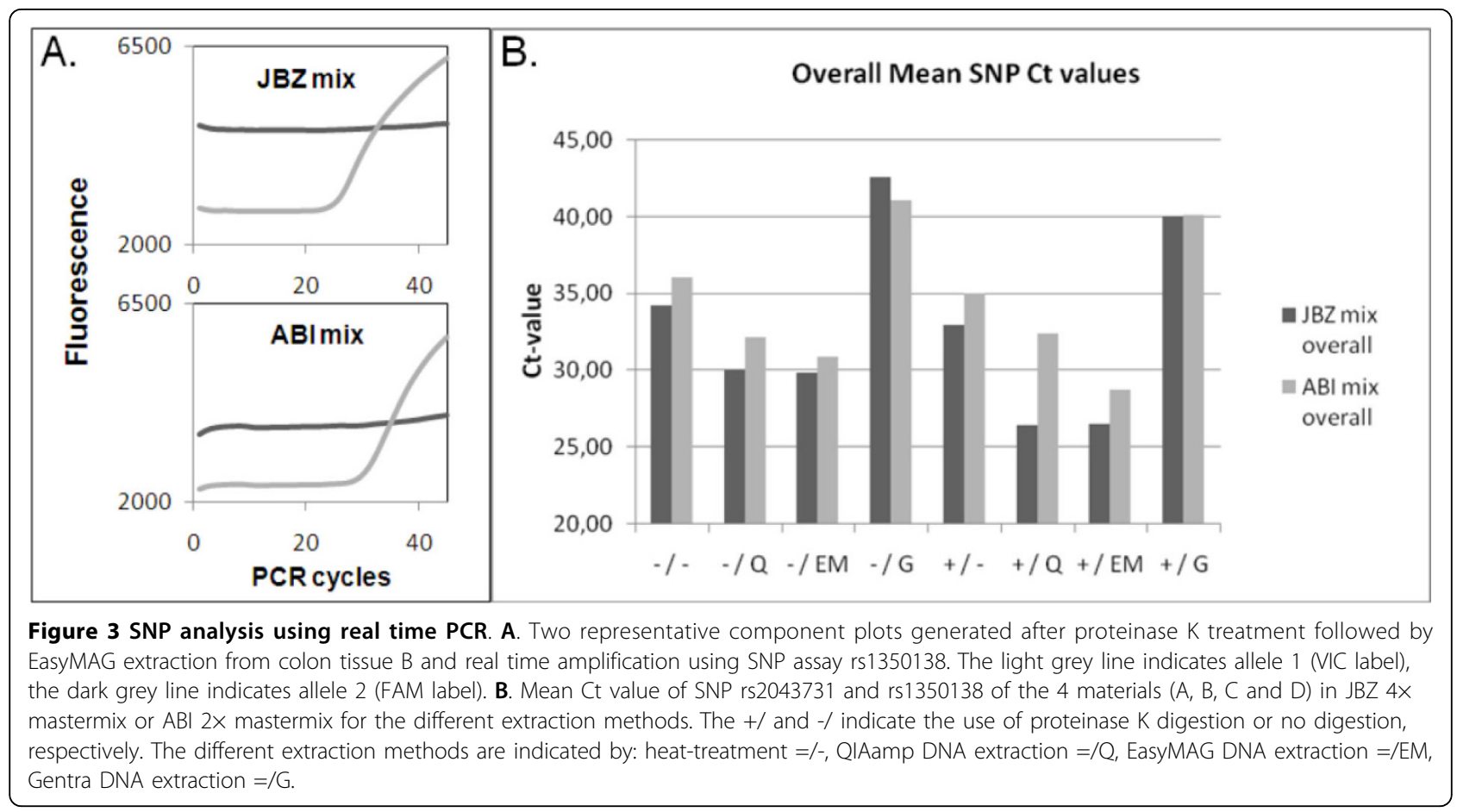

influence nucleic acid fragmentation [17]. In addition, the DNA extraction methods were studied using a limited number of samples. However the consistency of results justify several conclusions.

Gentra DNA extraction can be successfully employed on blood samples [28-32]. However, the reduced amplification of PhHV, the internal control virus, after Gentra extraction showed that the Gentra method was not able to sufficiently remove the inhibitory substances (figure 2). In addition, $\mathrm{Ct}$ values $<27.7$ generated by amplifying
PhHV DNA extracted by the other methods imply that proteinase $\mathrm{K}$ digestion is not necessary for the removal of possibly present inhibitory substances.

QIAamp as well as EasyMAG are both methods that are currently widely used in routine molecular diagnostics regarding the detection of pathogens, e.g. HPV detection [33,34], and mutation screening in cancer-critical genes, e.g. K-ras mutation detection [10]. With regard to real time SNP detection both methods performed well after proteinase $\mathrm{K}$ digestion. In line with

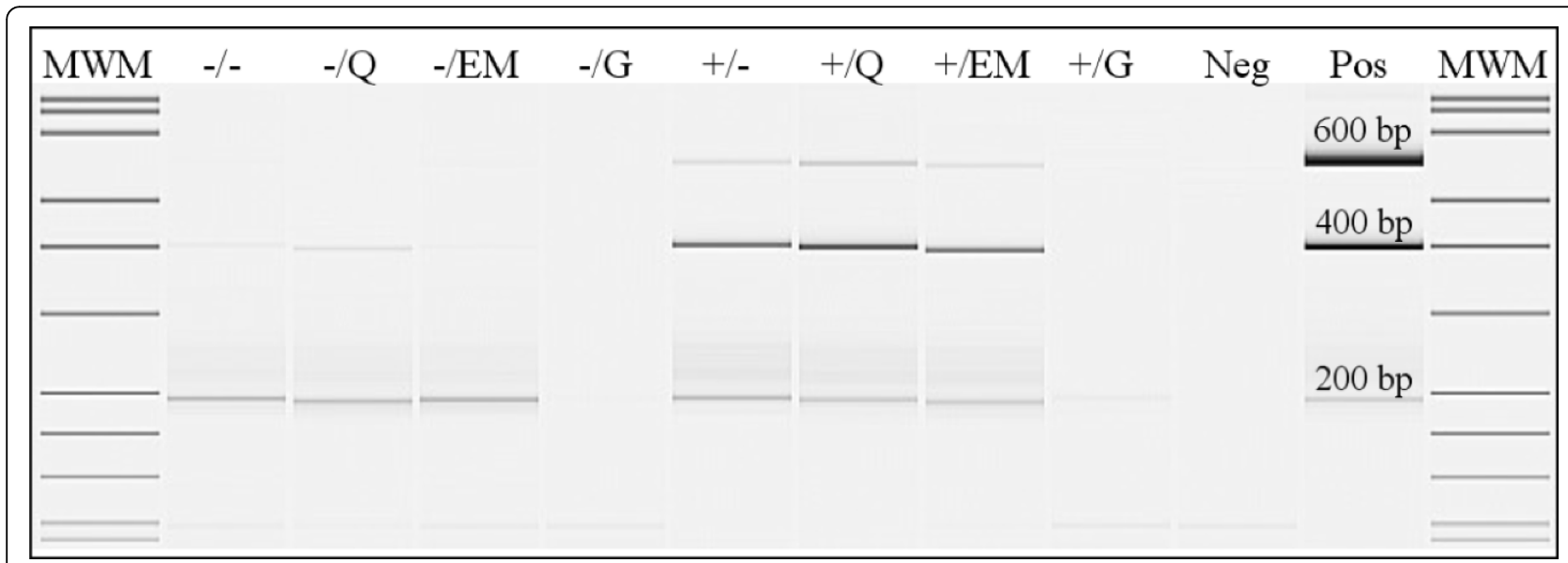

Figure 4 Assessment of maximum amplicon length: visualisation on gel. Gel image of 200-400-600 bp multiplex PCR-products of representative tissue B. The $+/$ and $-/$ indicate the use of proteinase $\mathrm{K}$ digestion or no digestion, respectively. The different extraction methods are indicated by: heat-treatment =/-, QIAamp DNA extraction =/Q, EasyMAG DNA extraction =/EM, Gentra DNA extraction $=/ \mathrm{G}$. Neg $=$ ultrapure water in PCR, POS = QIAamp extracted DNA from EDTA-blood. 


\section{PCR product yield}

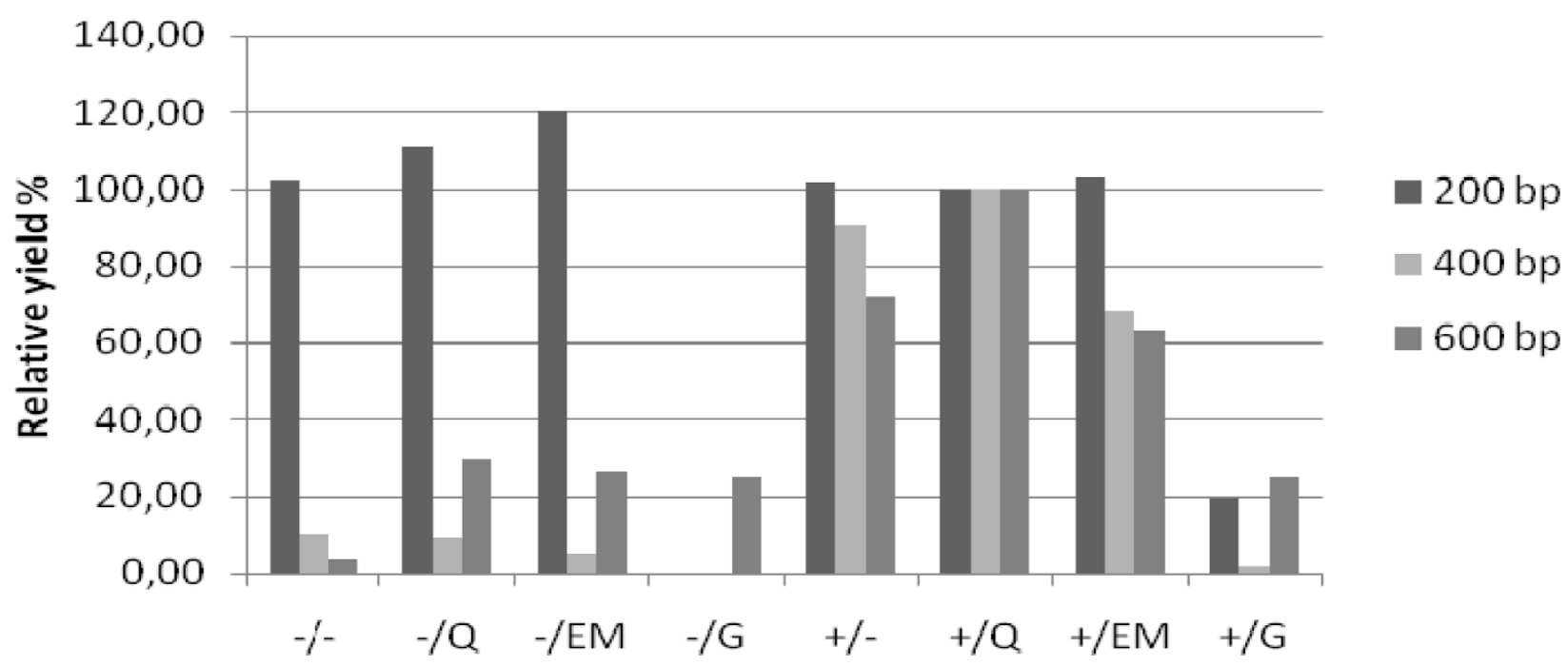

Figure 5 Assessment of maximum amplicon length: PCR product yield. Mean relative yield (\%) of 200, 400 and 600 bp PCR products of 4 materials (A, B, C and D). The prot. $K+$ QlAamp extraction's yield was set at 100\%. The $+/$ and $-/$ indicate the use of proteinase $K$ digestion or no digestion, respectively. The different extraction methods are indicated by: heat-treatment =/-, QIAamp DNA extraction =/Q, EasyMAG DNA extraction $=/$ EM, Gentra DNA extraction $=/ \mathrm{G}$.

previous findings (e.g. $[35,36])$ we observed that proteinase $\mathrm{K}$ digestion is required for optimal purification of paraffin-embedded DNA. The homebrew JBZ $4 \times$ mastermix yielded better results than the commercial $A B I$ $2 \times$ mastermix: fluorescent signals were slightly higher and $\mathrm{Ct}$ values lower, suggesting a better real time PCR environment for SNP amplification (figure 3A and 3B). The absence and presence of $>200 \mathrm{bp}$ PCR products after multiplex PCR (figure 4 and 5) of non-digested and digested samples (resp.) indicate that proteinase $\mathrm{K}$ treatment plays an important role in proper purification of fragments $>200 \mathrm{bp}$. Also for RNA it has been shown that small molecules are recovered more easily from FFPE tissues than larger RNA molecules $[27,37]$. The relatively high $200 \mathrm{bp}$ PCR product yield for the extraction methods without proteinase $\mathrm{K}$ digestion is probably due to the lack of competition for PCR ingredients by the absence of amplification of the higher molecular DNA targets, which are known to be extracted better when proteinase $\mathrm{K}$ digestion is used in contrast to no digestion $[35,36]$. This observation is important with regard to applications that target stretches of DNA > 200 bp, e.g. STR testing, P53 sequencing and APO-E genotyping [38-40]. Overall multiplex PCR results after Gentra extraction were very poor.

During the processes of paraffin embedding, sectioning and further analysis by (real time) PCR, small traces of foreign DNA, e.g. introduced by floater tissue or a contaminated microtome blade, may contaminate the material under investigation thereby possibly influencing interpretation of results $[41,42]$. Thus, caution is advised when using FFPE tissues in combination with molecular techniques. In addition, we routinely process paraffin blocks without tissue, which we use as negative controls. DNA extracts from these blocks may generate real time PCR signals above Ct 35 . To be sure that the signal under investigation is not due to background, we set the cut-off $\mathrm{Ct}$ value at 33 when using a SNP-profiling assay for identity confirmation [43], implicating that test results with $\mathrm{Ct}$ values $>33$ were rejected, whereas test results with $\mathrm{Ct}$ values $<33$ were accepted.

In summary, the Gentra extraction appeared not suitable to purify DNA from FFPE tissues. We speculate that this is possibly due to the methods' inability to remove DNA-tissue protein cross-links, resulting in loss of DNA during the washing steps of the DNA extraction method. In addition, column shredding, by which Gentra samples are lysed, could be less successful than guanidinium thiocyanaat lysis used by both the QIAamp and EasyMAG extraction methods. The other three methods were suitable for purifying DNA from paraffinembedded tissues, but all of them required proteinase $\mathrm{K}$ digestion. For real time SNP detection, both QIAamp and EasyMAG DNA extraction performed best. For amplification of longer DNA fragments -up to $600 \mathrm{bp}$-, the QIAamp DNA-blood-mini-kit extraction was most 
suitable, followed by heat-treatment and EasyMAG extraction. An advantage of the heat-treatment and EasyMAG was the reduced hands-on time (when extracting 24 samples: approximately $60 \mathrm{~min}$. for QIAamp versus $5 \mathrm{~min}$. for heat-treatment and $25 \mathrm{~min}$. for EasyMAG).

\section{Conclusions}

We conclude that the extraction method significantly influences downstream molecular analysis, which is in line with the findings of previous studies [17,20-24]. The Gentra Capture-Column-kit is not suitable for DNA recovery from FFPE tissues. Of the four methods tested QIAamp DNA-blood-mini-kit extraction and EasyMAG NucliSens extraction performed best for real time SNP detection. Amplification of 400-600 bp fragments appeared most successful after QIAamp isolation followed by the heat-treatment and EasyMAG.

Thus the method used for DNA isolation from FFPE tissues should be matched with the intended application.

\section{Abbreviations}

FFPE: formalin-fixed paraffin-embedded; SNP: single nucleotide polymorphism; Ct value: cycle threshold value; the number of cycles required for the fluorescent signal to cross the threshold (i.e. exceeds background level); PCR: polymerase chain reaction; PhHV: phocine herpes virus; SDS: sequence detection system;

\section{Acknowledgements}

We thank Kathelijn Geraats-Peters for critical reading of this manuscript.

\section{Author details}

'Laboratory of Molecular Diagnostics, Jeroen Bosch Hospital,

's-Hertogenbosch, The Netherlands. 'Laboratory of Pathology, Jeroen Bosch Hospital, 's-Hertogenbosch, The Netherlands. ${ }^{3}$ Medical Microbiology and Infection Control, VU University Medical Center, Amsterdam, The Netherlands.

\section{Authors' contributions}

CJJH participated in the design of the study, carried out all molecular experiments and drafted the manuscript. JD performed the tissue processing. JCvdL participated in drafting the manuscript and supplied the tissues. PHMS and MHAH participated in the design of the study and in drafting the manuscript. All authors read and approved the final manuscript.

\section{Competing interests}

The authors declare that they have no competing interests.

Received: 30 April 2010 Accepted: 14 September 2010 Published: 14 September 2010

\section{References}

1. Shibata DK, Arnheim N, Martin WJ: Detection of human papillomavirus in paraffin-embedded tissue using the polymerase chain reaction. J Exp Med 1988, 167:225-230.

2. Brandsma J, Lewis AJ, Abramson AL, Manos MM: Detection and typing of papillomavirus DNA in formalin-fixed, paraffin-embedded tissue. Arch Otolaryngal 1990, 116:844-848.

3. Cao M, Xiao X, Egbert B, Darragh TM, Yen TSB: Rapid detection of cutaneous herpes simplex virus infection with the polymerase chain reaction. J Invest Dermatol 1989, 82:391-392
4. Unger ER, Vernon SD, Lee DR, Miller DL, Reeves WC: Detection of Human Papillomavirus in Archival Tissues: Comparison of In Situ Hybridization and Polymerase Chain Reaction. J Histochem Cytochem 1998, 46:535-540.

5. Staudach EA, Dietze O, Hauser-Kronberger C: Comparison of real-time PCR signal-amplified in situ hybridization and conventional PCR for detection and quantification of human papillomavirus in archival cervical cancer tissue. J Clin Microbiol 2004, 42:3758-3765.

6. Johansen IS, Thomsen VØ Forsgren A, Hansen BF, Lundgren B: Detection of Mycobacterium tuberculosis complex in formalin-fixed, paraffinembedded tissue specimens with necrotizing granulomatous inflammation by strand displacement amplification. J Mol Diagn 2004, 6:231-236.

7. Beqaj SH, Flesher R, Walker GR, Smith SA: Use of the real-time PCR assay in conjunction with MagNA Pure for the detection of mycobacterial DNA from fixed specimens. Diagn Mol Pathol 2007, 16:169-173.

8. Burmer GC, Rabinovitch PS, Loeb LA: Analysis of c-Ki-ras mutations in human colon carcinoma by cell sorting, polymerase chain reaction, and DNA sequencing. Cancer Res 1989, 49:2141-2146.

9. Lyons J, Landis CA, Harsh G, Vallar L, Grunewald K, Feichtinger H, Duh QY, Clark OH, Kawasaki E, Bourne H, McCormick F: Two G protein oncogenes in human endocrine tumors. Science 1990, 249:655-659.

10. Kramer D, Thunnissen FB, Gallegos-Ruiz MI, Smit EF, Postmus PE, Meijer CJ Snijders PJ, Heideman DA: A fast, sensitive and accurate high resolution melting (HRM) technology-based assay to screen for common K-ras mutations. Cell Oncol 2009, 31:161-167.

11. Thibodeau SN, Bren G, Schaid D: Microsatellite instability in cancer of the proximal colon. Science 1993, 260:816-819.

12. Riet van der P, Karp D, Framar A, Wei Q, Grossman L, Tokino K, Ruppert JM, Sidransky D: Progression of basal cell carcinoma through loss of chromosome $9 q$ and inactivation of a single p53 allele. Cancer Res 1994, 54:25-27.

13. Iverson AA, Gillett C, Cane P, Santini CD, Vess TM, Kam-Morgan L, Wang A, Eisenberg M, Rowland CM, Hessling JJ, Broder SE, Sninsky JJ, Tutt A, Anderson S, Chang SY: A single-tube quantitative assay for mRNA levels of hormonal and growth factor receptors in breast cancer specimens. $J$ Mol Diagn 2009, 11:117-130.

14. Lehmann $U$, Kreipe $H$ : Real-time PCR analysis of DNA and RNA extracted from formalin-fixed and paraffin-embedded biopsies. Methods 2001, 25:409-418.

15. Kayser K, Stute H, Lübcke J, Wazinski U: Rapid microwave fixation - a comparative morphometric study. Histochem J 1988, 20:347-352.

16. Perlmutter MA, Best CJ, Gillespie JW, Gathright Y, González S, Velasco A, Linehan WM, Emmert-Buck MR, Chuaqui RF: Comparison of snap freezing versus ethanol fixation for gene expression profiling of tissue specimens. J Mol Diagn 2004, 6:371-377.

17. Gilbert MTP, Haselkorn T, Bunce M, Sanchez JJ, Lucas SB, Jewell LD, Van Marck E, Worobey M: The Isolation of Nucleic Acids from Fixed, Paraffin -Embedded Tissues- Which Methods Are Useful When? PLoS One 2007, 2: e537.

18. Quach N, Goodman M, Shibata D: In vitro artifacts after formalin fixation and error prone translesion synthesis during PCR. BMC Biotechnology 2004, 4:1.

19. Bonin S, Petrera F, Niccolini B, Stanta G: PCR analysis in archival postmortem tissues. Mol Pathol 2003, 56:184-186.

20. Dedhia P, Tarale S, Dhongde G, Khadapkar R, Das B: Evaluation of DNA Extraction Methods and Real Time PCR Optimization on Formalin-fixed Paraffin-embedded Tissues. Asian Pacific J Cancer Prev 2007, 8:55-59.

21. Cao W, Hashibe M, Rao JY, Morgenstern H, Zhang ZF: Comparison of methods for DNA extraction from paraffin-embedded tissues and buccal cells. Cancer Detect Prev 2003, 27:397-404.

22. Chan PK, Chan DP, To KF, Yu MY, Cheung JL, Cheng AF: Evaluation of extraction methods from paraffin wax embedded tissues for PCR amplification of human and viral DNA. J Clin Pathol 2001, 54:401-403.

23. Rivero ER, Neves AC, Silva-Valenzuela MG, Sousa SO, Nunes FD: Simple salting-out method for DNA extraction from formalin-fixed, paraffinembedded tissues. Pathol Res Pract 2006, 202:523-529.

24. Wu L, Patten N, Yamashiro CT, Chui B: Extraction and Amplification of DNA From Formalin-Fixed, Paraffin-Embedded Tissues. Appl Immunohistochem Mol Morphol 2002, 10:269-274. 
25. van Doornum GJ, Guldemeester J, Osterhaus AD, Niesters HG: Diagnosing herpesvirus infections by real-time amplification and rapid culture. J Clin Microbiol 2003, 41:576-580.

26. Wolffs P, Grage H, Hagberg O, Rådström P: Impact of DNA Polymerases and Their Buffer Systems on Quantitative Real-Time PCR. J Clin Microbiol 2004, 42:408-411.

27. Li J, Smyth P, Cahill S, Denning K, Flavin R, Aherne S, Pirotta M, Guenther SM, O'Leary JJ, Sheils O: Improved RNA quality and TaqMan Preamplification method (PreAmp) to enhance expression analysis from formalin fixed paraffin embedded (FFPE) materials. BMC Biotechnol 2008, 8:10.

28. Kowalski A, Radu D, Gold B: Colorimetric microwell plate detection of the factor V Leidenmutation. Clin Chem 2000, 46:1195-1198.

29. Fahle GA, Fischer SH: Comparison of six commercial DNA extraction kits for recovery of cytomegalovirus DNA from spiked human specimens. $J$ Clin Microbiol 2000, 38:3860-3863.

30. Esteve $M$, Rosinach $M$, Fernández-Banãres F, Farré $C$, Salas A, Alsina $M$, Vilar P, Abad-Lacruz A, Forné M, Mariné M, Santaolalla R, Espinós JC, Viver JM: Spectrum of gluten-sensitive enteropathy in firstdegree relatives of patients with coeliac disease: clinical relevance of lymphocytic enteritis. Gut 2006, 55:1739-1745.

31. Pruthi RK, Rodriguez V, Allen C, Slaby JA, Schmidt KA, Plumhoff EA: Molecular analysis in a patient with severe factor VII deficiency and an inhibitor: report of a novel mutation (S103G). European Eur J Haematol 2007, 79:354-359.

32. Hillman MA, Wilke RA, Yale SH, Vidaillet HJ, Caldwell MD, Glurich I, Berg RL, Schmelzer J, Burmester JK: A prospective, randomized pilot trial of modelbased warfarin dose initiation using CYP2C9 genotype and clinical data. Clin Med Res 2005, 3:137-145.

33. Koidl C, Bozic M, Hadzisejdic I, Grahovac M, Grahovac B, Kranewitter W, Marth $\mathrm{E}$, Kessler $\mathrm{HH}$ : Comparison of molecular assays for detection and typing of human papillomavirus. Am J Obstet Gynecol 2008, 199(144):e1-6.

34. Klaassen $\mathrm{CH}$, Prinsen $\mathrm{CF}$, de Valk HA, Horrevorts AM, Jeunink MA, Thunnissen FB: DNA microarray format for detection and subtyping of human papillomavirus. J Clin Microbiol 2004, 42:2152-2160.

35. Isola J, DeVries S, Chu L, Ghazvini S, Waldman F: Analysis of changes in DNA sequence copy number by comparative genomic hybridization in archival paraffin-embedded tumor samples. Am J Pathol 1994, 145:1301-1308.

36. Banerjee SK, Makdisi WF, Weston AP, Mitchell SM, Campbell DR: Microwave-based DNA extraction from paraffin-embedded tissue for PCR amplification. BioTechniques 1995, 18:768-773.

37. Li J, Smyth P, Flavin R, Cahill S, Denning K, Aherne S, Guenther SM, O'Leary JJ, Sheils O: Comparison of miRNA expression patterns using total RNA extracted from matched samples of formalin-fixed paraffinembedded (FFPE) cells and snapfrozen cells. BMC Biotechnol 2007, 7:36.

38. Moretti TR, Baumstark AL, Defenbaugh DA, Keys KM, Smerick JB, Budowle B: Validation of short tandem repeats (STRs) for forensic usage: performance testing of fluorescent multiplex STR systems and analysis of authentic and simulated forensic samples. J Forensic Sci 2001, 46:647-660.

39. Ahrendt SA, Halachmi S, Chow JT, Wu L, Halachmi N, Yang SC, Wehage S, Jen J, Sidransky D: Rapid p53 sequence analysis in primary lung cancer using an oligonucleotide probe array. Proc Natl Acad Sci USA 1999, 22:7382-7387.

40. Gioia L, Vogt LJ, Freeman WM, Flood A, Vogt BA, Vrana KE: PCR-based apolipoprotein $\mathrm{E}$ genotype analysis from archival fixed brain. J Neurosci Methods 1998, 80:209-214.39.

41. Fox EA: Preparation of DNA from fixed, paraffin-embedded tissue. Curr Protoc Hum Genet 2001.

42. Mosse CA, Stumph JR, Best DH, Vnencak-Jones CL: A B-cell lymphoma diagnosed in "floater" tissue: implications of the diagnosis and resolution of a laboratory error. Am J Med Sci 2009, 338:248-251.

43. Huijsmans R, Damen J, van der Linden $H$, Hermans M: Single nucleotide polymorphism profiling assay to confirm the identity of human tissues. $J$ Mol Diagn 2007, 9:205-213.

doi:10.1186/1756-0500-3-239

Cite this article as: Huijsmans et al: Comparative analysis of four methods to extract DNA from paraffin-embedded tissues: effect on downstream molecular applications. BMC Research Notes 2010 3:239.

\section{Submit your next manuscript to BioMed Central and take full advantage of:}

- Convenient online submission

- Thorough peer review

- No space constraints or color figure charges

- Immediate publication on acceptance

- Inclusion in PubMed, CAS, Scopus and Google Scholar

- Research which is freely available for redistribution 